KINETIK, Vol.1, No.3, November 2016, Hal.163-172

ISSN : 2503-2259,

E-ISSN : 2503-2267

\title{
Prototipe Sistem Kontrol Jarak Jauh Beberapa Alat Pendingin Ruangan Berbasis Raspberry PI
}

\author{
Mochamad Subianto \\ Universitas Ma Chung \\ mochamad.subianto@machung.ac.id
}

\begin{abstract}
Abstrak
Saat ini pengendalian on/off berbagai peranti listrik kebanyakan masih dikendalikan dengan menekan tombol sakelar atau remote yang penggunaannya dengan jarak yang dekat. Untuk menjawab kebutuhan masyarakat tentang sistem kontrol yang cepat dan dinamis diperlukan suatu teknologi sistem kontrol jarak jauh yang memungkinkan proses secara cepat agar dapat menghemat waktu dan tenaga khususnya pengendalian beberapa alat pendingin ruangan yang berada di beberapa ruangan. Penelitian ini merupakan penelitian lanjutan dari peneliti terdahulu dan menggunakan perangkat yang mempunyai teknologi terbaru, yaitu Raspberry Pi sebagai pengendali untuk membuat suatu sistem kontrol beberapa AC (Air Conditioner) pada ruangan yang berbeda secara jarak jauh. Diharapkan dapat sebagai salah satu solusi untuk perkembangan gaya hidup dan dinamika sosial saat ini yang semakin mementingkan kepraktisan dan efisiensi. Metodologi penelitian yang akan digunakan menggunakan metodologi Waterfall dengan tahap-tahapannya, yaitu tinjauan pustaka, analisis kebutuhan pengguna, analisis sistem, perancangan sistem, implementasi dan pengujian. Hasil akhir dari penelitian adalah prototipe pengendali jarak jauh beberapa perangkat AC Raspberry Pi.
\end{abstract}

Kata kunci: Air Conditioner, Raspberry Pi, Sistem Kontrol, Jarak Jauh

\section{Abstract}

Currently, on/off controlling for electronic devises is using manual switcher or remote control over quite short distance. A fast and dynamic controlling system is needed to save time and energy, specifically for controlling Air Conditioner (AC) used in several rooms. This research is a follow-up of the previous research and using the latest technology, Raspberry Pi, to control ACs in different rooms from distance. This system is expected to be a solution to respond the lifestyle and social dynamics that practical and efficiency-oriented. Waterfall method is used in this research, including all the steps such as literature review, users' needs analysis, system analysis, system designing, implementation, and experiments. The final result of this research is a prototype of Raspberry Pi long-distance controller for AC devices.

Keywords: Air Conditioner, Raspberry Pi, Control Systems, Long Distance

\section{Pendahuluan}

Saat ini pengendalian on/off berbagai peranti listrik kebanyakan masih dikendalikan dengan menekan tombol sakelar atau remote, yang penggunaannya dengan jarak dekat. Perkembangan gaya hidup dan dinamika sosial saat ini menunjukkan semakin pentingnya kepraktisan dan efisiensi menyebabkan kebutuhan untuk mengendalikan peranti listrik tidak hanya dilakukan secara jarak dekat tetapi bisa dilakukan jarak jauh [1].

Seiring berkembangnya teknologi, kebutuhan masyarakat tentang sistem kendali yang cepat dan dinamis semakin meningkat. Oleh karena itu, diperlukan suatu teknologi sistem kendali jarak jauh yang memungkinkan proses secara cepat agar dapat menghemat waktu dan tenaga.

Manusia membutuhkan lingkungan udara yang nyaman untuk dapat bekerja secara optimal. Pada ruangan perkuliahan, pengaturan dan pengendalian yang baik terhadap ruangan akan dapat meredakan sebagian ketegangan psikologi, sehingga dapat membuat kenyamanan yang lebih baik dan meningkatkan kesehatan badaniah dan kemampuan fisik. Salah satu sarana untuk menciptakan kondisi yang demikian adalah dengan melengkapi ruangan perkuliahan dengan alat penyejuk ruangan dalam hal ini adalah AC (Air Conditioner). Sehingga 
AC yang tersedia di pasaran saat ini telah dilengkapi dengan remote control yang hanya dapat mengontrol $A C$ dalam jarak dekat.

Persoalan pengendalian AC jarak dekat muncul pada saat jumlah AC dinyatakan banyak dan berada di beberapa ruangan berbeda. Hal tersebut memerlukan waktu cukup banyak untuk memastikan bahwa AC sudah off atau on dengan melihat satu persatu setiap unit AC. Hal tersebut lebih menyulitkan jika ditambah ruangan berada di tempat lokasi berjauhan atau di lantai yang berbeda.

Mengenai pengendalian AC jarak jauh sudah dilakukan oleh beberapa peneliti, yaitu Marsud Hamid tahun 2008, tentang kendali AC jarak jauh dengan menggunakan telephone genggam. Pada penelitian tersebut perangkat pengontrol yang digunakan adalah AVR AT89S51 yang dihubungkan dengan handphone sebagai penerima instruksi dari handphone lain yang dipegang oleh user [2]. System ini mempunyai kelemahan jika diterapkan untuk AC dengan jumlah banyak yaitu membutuhkan dana besar karena setiap AC membutuhkan satu buah handphone.

Penelitian selanjutnya dilakukan oleh Nugra Perkasa tahun 2013 tentang sistem kendali jarak jauh melalui Jaringan komputer untuk mengontrol penerangan ruangan dan Air Conditioner (AC) Pada Laboratorium STIMIK AMIKOM Yogyakarta dalam bentuk maket berbasis Mikrokontroler Arduino [3]. Sistem jauh lebih lengkap dalam hal objek kendalinya, yakni lampu dan AC serta pengunci pintu sebagai pelengkap sistem. Akan tetapi sistem ini berjalan hanya untuk satu ruangan saja.

Penelitian selanjutnya dilakukan oleh Mochamad Subianto tahun 2014 tentang sistem kendali jarak jauh untuk ruangan dan perangkat elektronik menggunakan Raspberry Pi [4].

Dari permasalahan tersebut maka dibutuhkan penelitian lanjutan untuk membuat suatu sistem kendali beberapa AC (Air Conditioner) dan pada ruangan yang berbeda secara jarak jauh menggunakan Raspberry Pi sebagai kontroler dan diharapkan menjadi satu solusi untuk perkembangan gaya hidup dan dinamika sosial saat ini yang semakin mementingkan kepraktisan dan efisiensi.

\section{Metode Penelitian}

Metode penelitian ini menggunakan konsep Waterfall. Waterfall adalah suatu metodologi pengembangan perangkat lunak yang mengusulkan pendekatan kepada perangkat lunak sistematik dan sekuensial yang mulai pada tingkat kemajuan sistem pada seluruh analisis, design, kode, pengujian dan pemeliharaan. Tahap-tahap dalam metodologi Waterfall sebagai berikut:

\subsection{Tinjauan Pustaka}

Dalam penelitian ini menggunakan model tinjauan pustaka. Model tinjauan pustaka digunakan untuk mencari informasi cara bagaimana sebuah aplikasi yang ada pada komputer dapat diintegrasikan untuk memberitahukan tanda informasi jam pelajaran. Model perancangan sistem informasi yang digunakan untuk melihat proses-proses yang ada sekarang dan sekaligus untuk merancang sistem baru yang akan dibuat dengan cara menggambarkan sebuah rancangan arsitektur aplikasi, rancangan tampilan input output, testing dan implementasi [5].

\subsection{Analisis Kebutuhan Pengguna}

Analisis kebutuhan pengguna merupakan kunci atas keberhasilan implementasi sistem. Penelitian ini menggunakan metode Observasi dan Wawancara dengan beberapa stakeholder yang terkait. Selanjutnya didefinisikan kebutuhan perusahaan dengan mengadakan analisis dengan metode Wawancara.

\subsection{Analisis Sistem}

Melakukan analisis terhadap requirement baik fungsional ataupun non fungsional yang dibutuhkan dalam perancangan dan pembuatan sistem. Gambar bentuk alur sistem (terlihat pada Gambar 1) yang diinginkan oleh pengelola gedung Universitas Ma Chung dalam pemakaian AC.

\subsection{Perancangan Sistem}

Perancangan merupakan proses tahapan yang fokusnya pada desain sistem yang hendak dibangun meliputi perancangan Data Flow Diagram, perancangan basis data, serta perancangan arsitektur aplikasi dan perangkat.

KINETIK Vol. 1, No. 3, November 2016: 163-172 


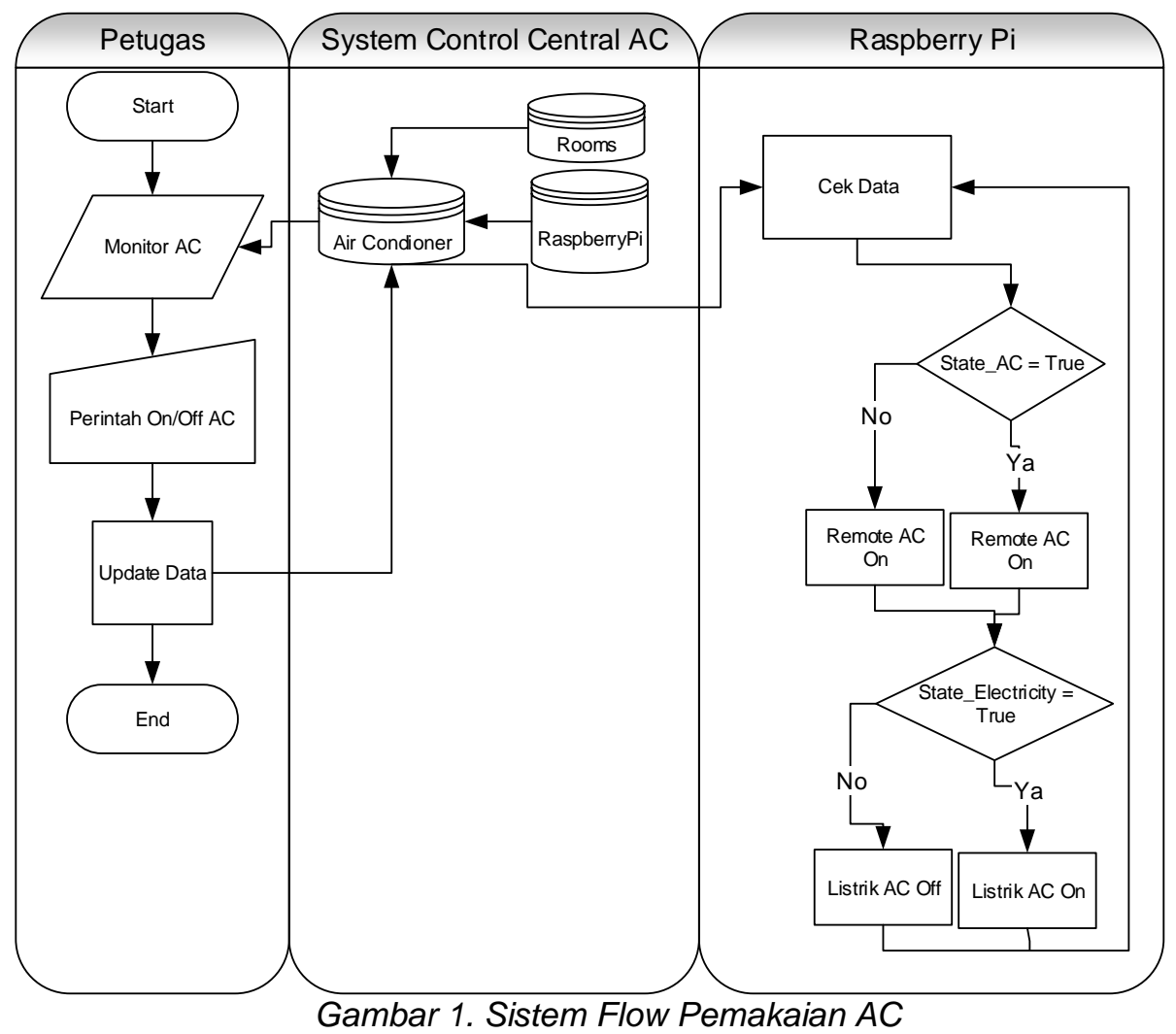

Perancangan awal sistem dalam penelitian ini adalah sebagai berikut:

\subsubsection{Arsitektur}

Arsitektur merupakan gambaran dari sistem yang akan dibuat. Arsitektur sistem kendali jarak jauh beberapa perangkat pendingin ruangan berbasis Raspberry $\mathrm{Pi}$ yang akan dibangun terlihat pada Gambar 2.

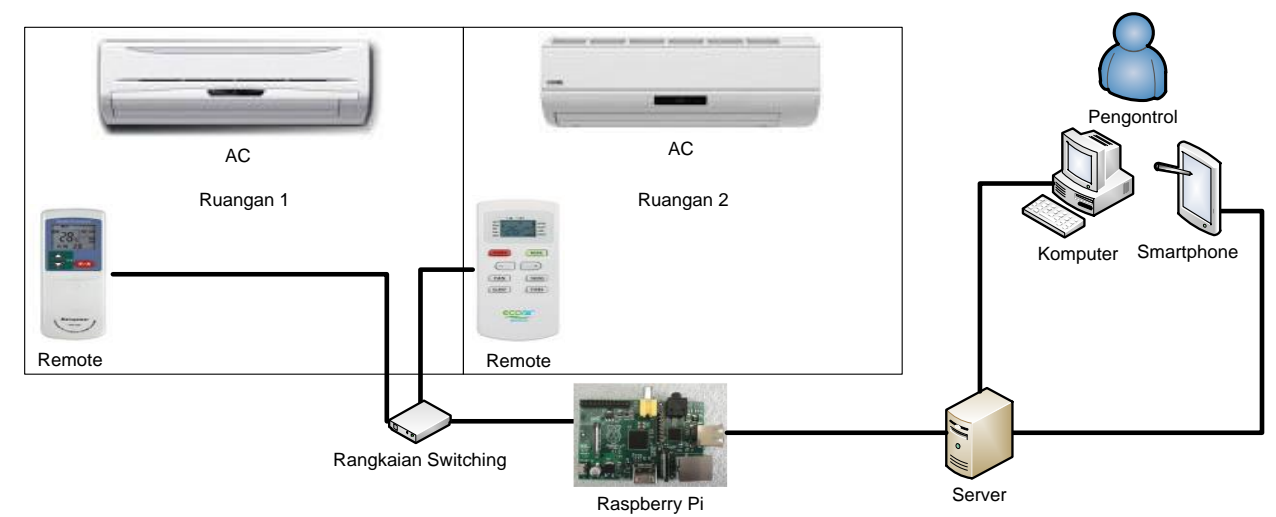

Gambar 2. Arsitektur Sistem Kontrol Jarak jauh Beberapa Perangkat Pendingin Ruangan Raspberry Pi

Arsitektur sistem pada Gambar 2 menunjukkan bahwa pusat kendali berada pada perangkat Raspberry $\mathrm{Pi}$. Raspberry $\mathrm{Pi}$ memberikan perintah ke rangkaian switching untuk melakukan on/off perangkat pendingin ruangan melalui remote. Pengguna dapat monitoring status dan dapat mengontrolnya melalui aplikasi yang ada pada komputer dan smartphone serta terhubung dengan server, kemudian server mengirimkan perintah ke Raspberry Pi. Setiap beberapa menit Raspberry $\mathrm{Pi}$ memberikan informasi status perangkat pendingin ruangan kepada server, kemudian melalui aplikasi pengguna dapat mengetahui status perangkat pendingin ruangan menggunakan komputer atau smartphone. 


\subsubsection{Desain РCB Switcher Remote AC}

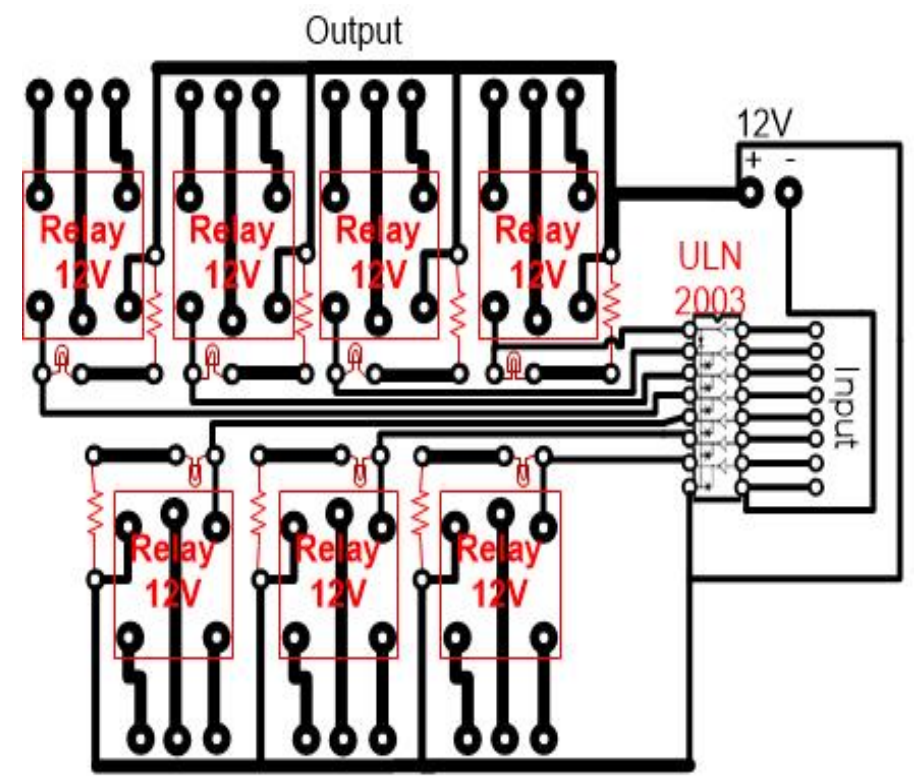

Output

Gambar 3. Desain PCB Switcher Remote AC

Rangkaian switch remote AC yang terlihat pada Gambar 3 terdiri dari IC ULN 2003, relay $12 \mathrm{~V}$ dan Resistor $1 \mathrm{KOhm}$ serta LED sebagai indikator yang berfungsi mengubah arus DC yang berasal dari Raspberry yang hanya $3 \mathrm{~V}$ menjadi lebih besar dengan maksimal daya $12 \mathrm{~V}$.

\subsubsection{Desain PCB Switcher Arus Listrik AC}

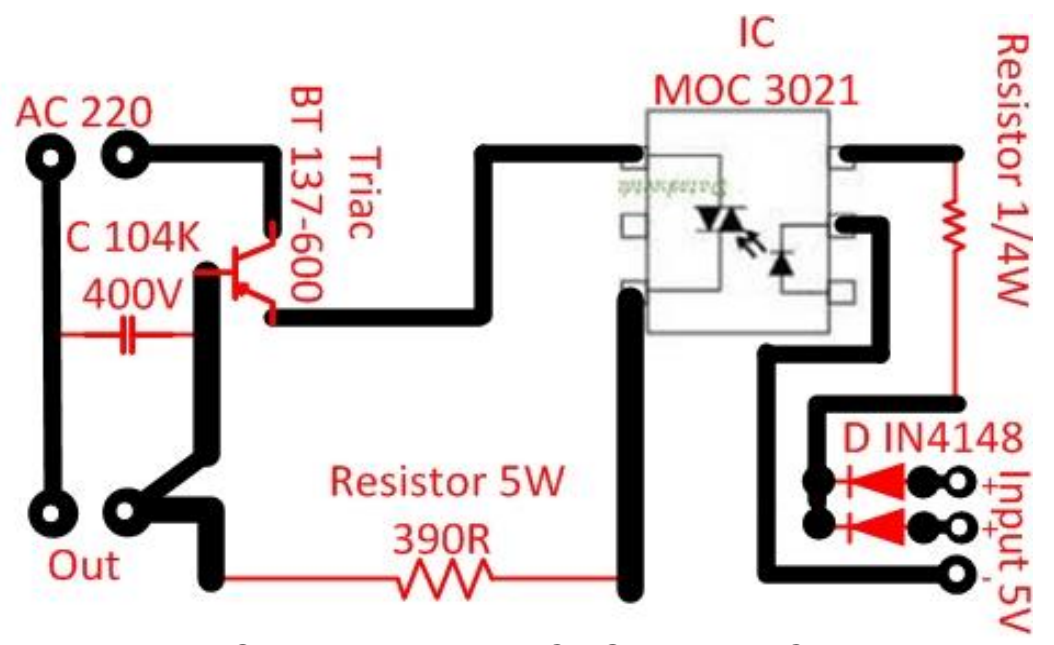

Gambar 4. Desain PCB Switching AC

Rangkaian switch arus listrik yang terlihat pada Gambar $4 \mathrm{~g}$ terdiri dari Triac BT 137600, Resistor 1/4W, Resistor 5W 390R, IC MOC 3021, Dioda IN4148, Kapasitor 104/400V berfungsi sebagai pemutus dan penghubung arus listrik AC. Input dari rangkaian switch arus listrik adalah daya DC 4-6V.

\subsubsection{Perancangan Database}

Sistem yang dibuat membutuhkan sebuah database untuk menyimpan data, sehingga komunikasi antar perangkat dapat dilakukan melalui database tersebut. Berikut rancangan database pada Gambar 5. 


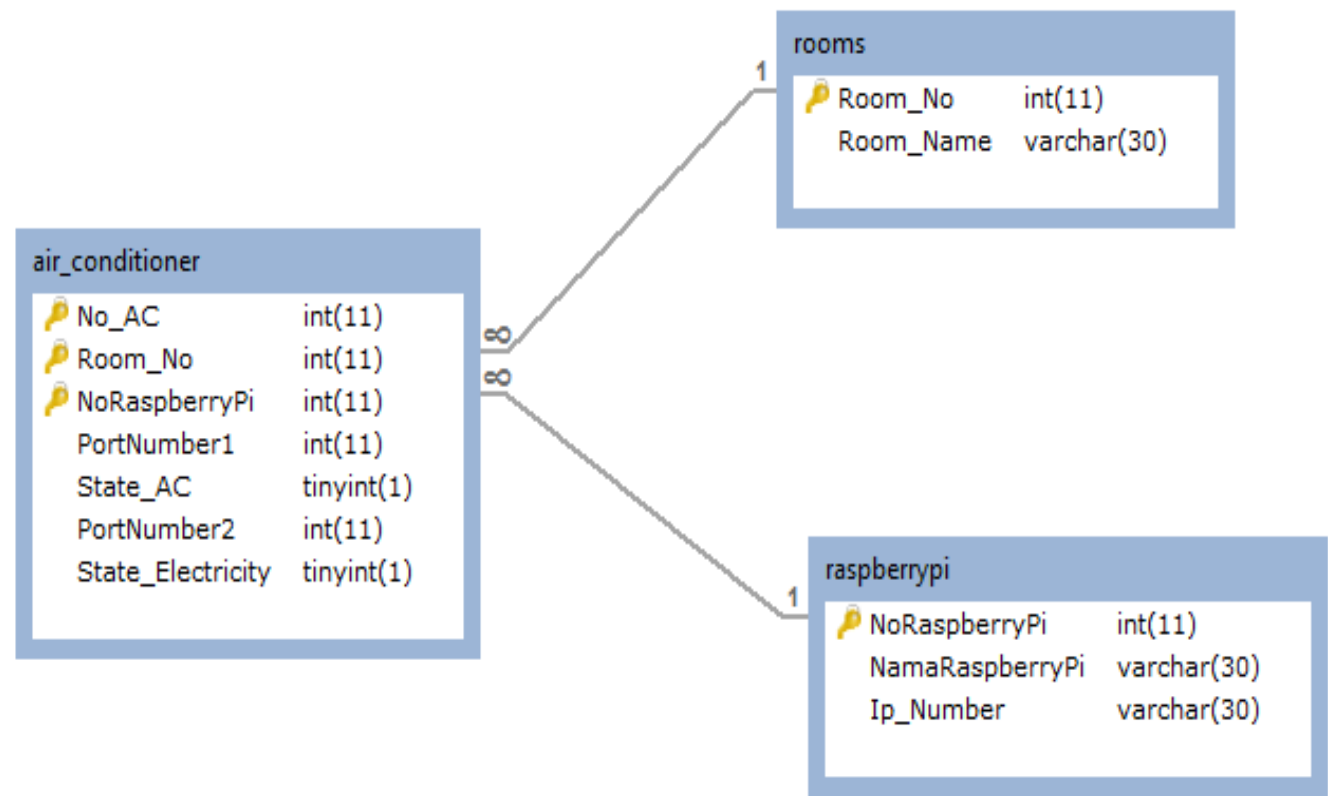

Gambar 5. Relasi Database

\section{Hasil Penelitian dan Pembahasan}

3.1 Implementasi

Berdasarkan desain PCB pada Gambar 3 dan Gambar 4, kemudian masuk ke tahap berikutnya dengan membeli beberapa perangkat dan peralatan yang dibutuhkan, serta hasil perakitan yang telah dilakukan dapat dilihat pada Gambar 6, Gambar 7, dan Gambar 8.

\subsubsection{Switcher Remote AC}

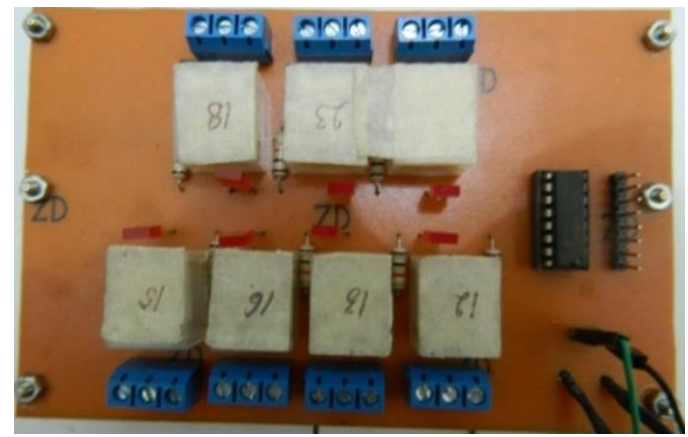

Gambar 6. Rangkaian Switcher Remote AC

\subsubsection{Switcher Arus Listrik AC}

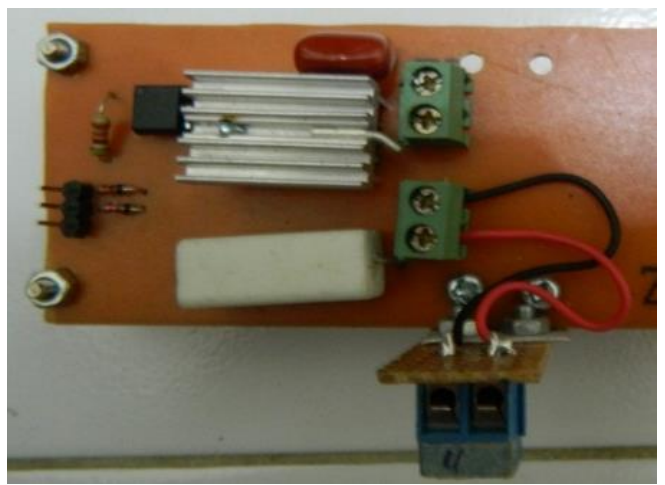

Gambar 7. Rangkaian Switching AC 


\subsubsection{Rangkaian Output Raspberry Pi}

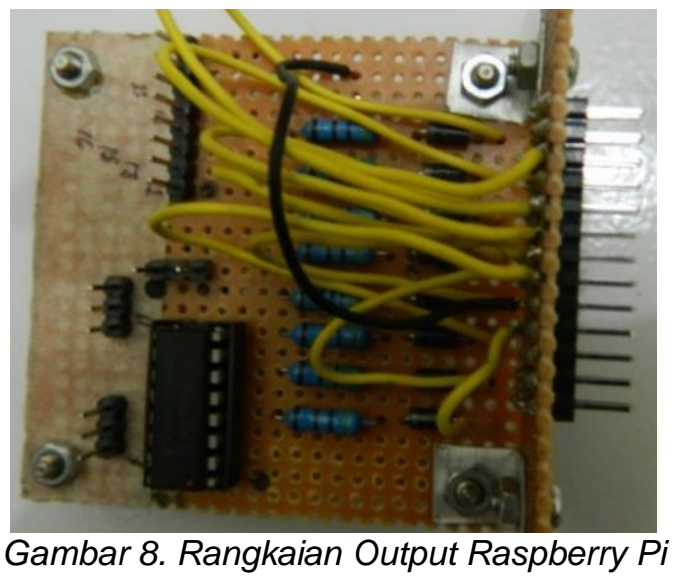

\subsection{Instalasi/Perakitan dan Hasil}

Install dan packaging dari beberapa rangkaian pada Bab 3.1 dapat dilihat pada Gambar 9:
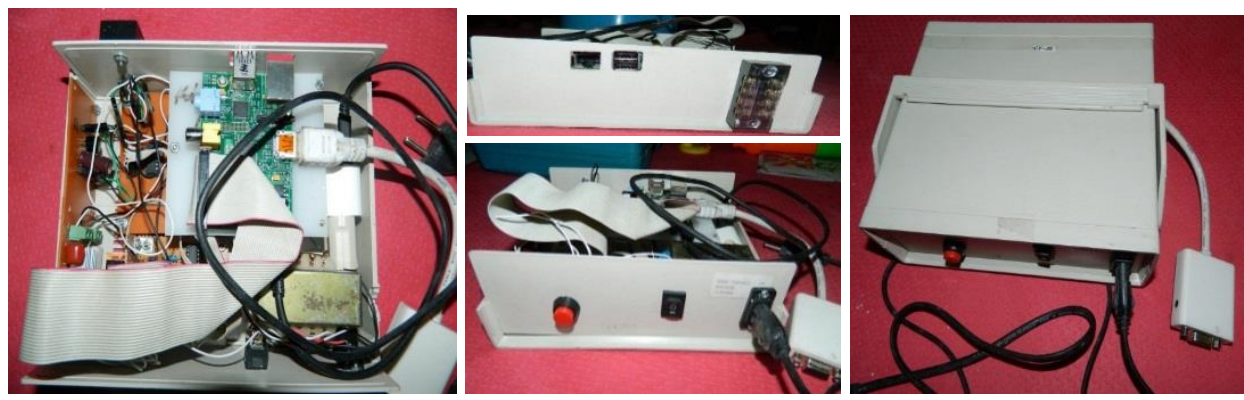

Gambar 9. Instalasi Rangkaian dan Packaging

Rangkaian yang sudah dirakit akan dikendalikan menggunakan perangkat lunak yang terlihat pada Gambar 9. Melalui aplikasi tersebut para pengguna dapat melakukan monitoring kondisi AC dan melakukan kendali jarak jauh untuk mematikan dan menyalakan AC. Aplikasi kendali AC jarak jauh ini mempunyai beberapa fitur, yaitu:

1. Manipulasi Data Master Ruangan

2. Manipulasi Data Master Raspberry PI

3. Manipulasi Data Master AC

Gambar 10 menunjukkan tampilan aplikasi menu, sekaligus monitoring kondisi AC. Dalam tampilan tersebut user dapat melihat kondisi AC, yaitu waktu AC telah aktif dan user dapat melakukan on/off AC melalui aplikasi tersebut.

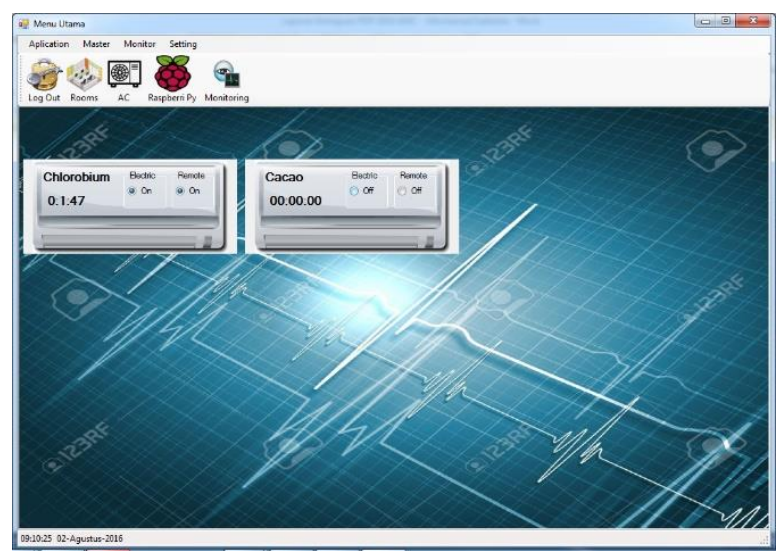

Gambar 10. Aplikasi Monitoring AC Jarak Jauh

KINETIK Vol. 1, No. 3, November 2016: 163-172 
Gambar 11 menunjukkan tampilan aplikasi untuk melakukan manipulasi data ruangan yang ada. Dengan melalui tampilan tersebut user dapat melakukan insert/update data ruangan yang akan dilakukan kendali AC.

Gambar 12 menunjukkan tampilan aplikasi untuk melakukan manipulasi data device Raspberry Pi. Dengan melalui tampilan tersebut user dapat melakukan insert/update data Raspberry Pi yang akan melakukan kendali AC.

Gambar 13 menunjukkan tampilan aplikasi untuk melakukan manipulasi data device AC. Dengan melalui tampilan tersebut user dapat melakukan insert/update data AC akan terkendali. Dalam hal ini, satu Raspberry Pi dapat mengontrol 4 buah AC sekaligus.

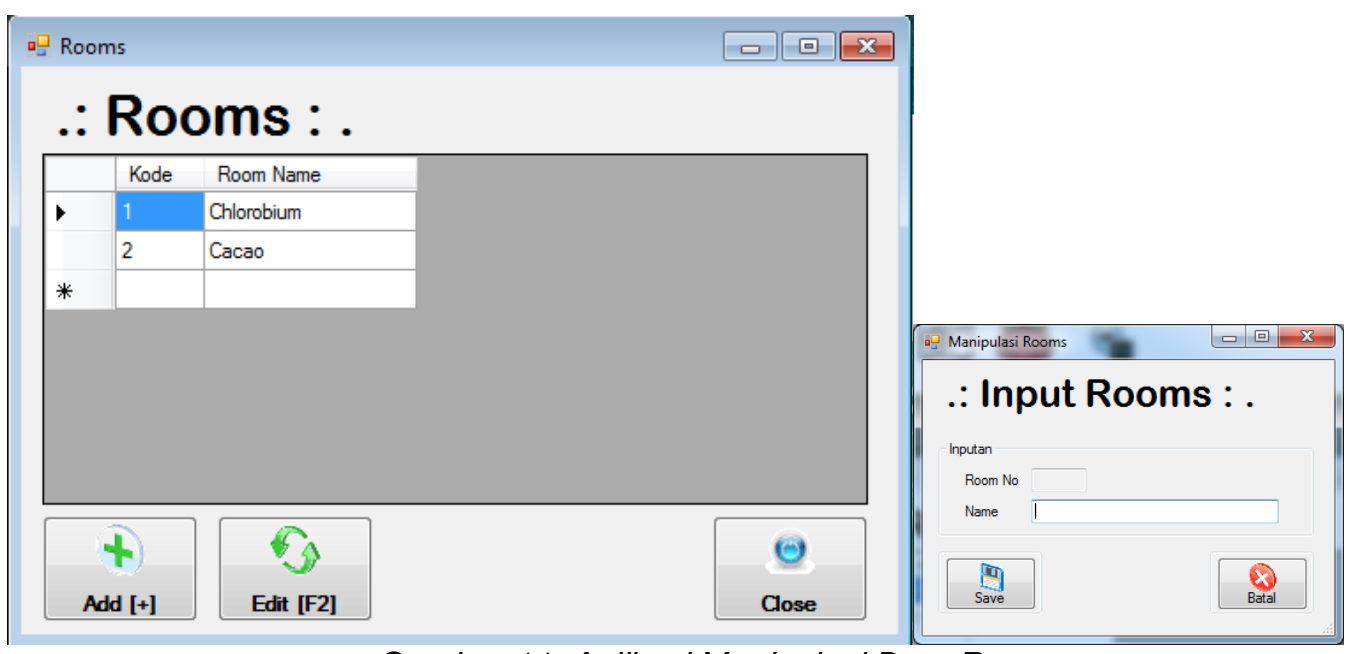

Gambar 11. Aplikasi Manipulasi Data Ruangan

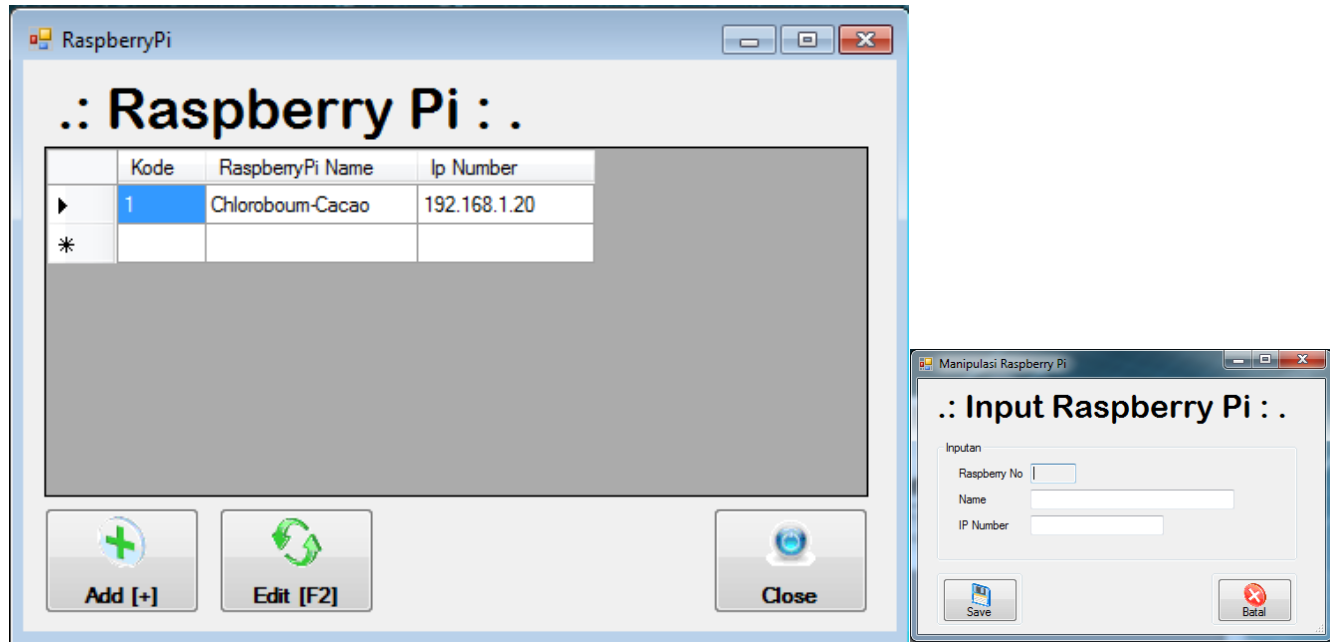

Gambar 12. Aplikasi Manipulasi Data Raspberry Pi

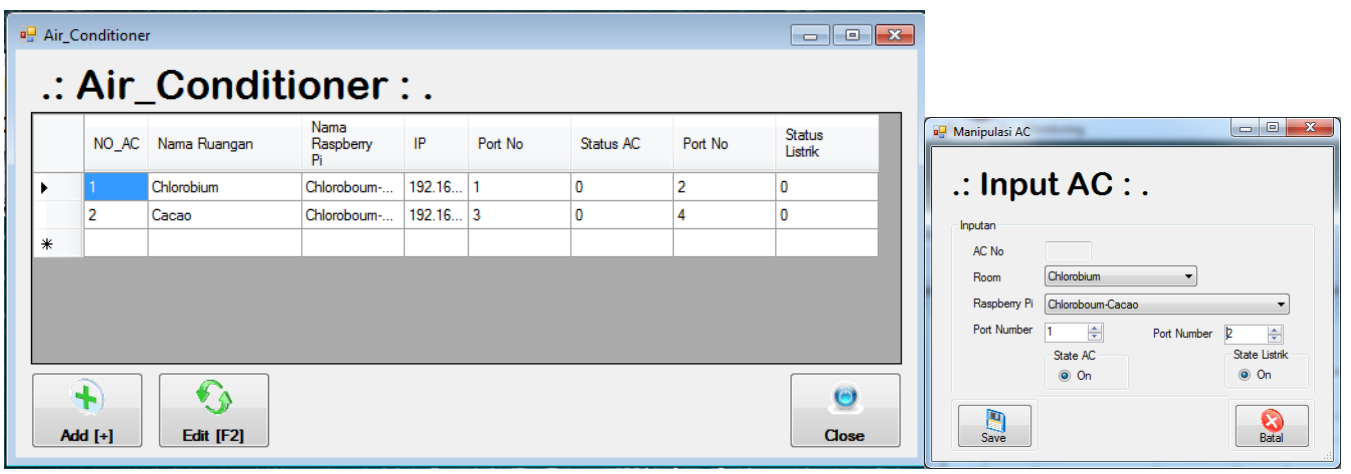

Gambar 13. Aplikasi Manipulasi Data AC 


\subsection{Uji Coba}

Beberapa rangkaian tersebut dilakukan pengujian keakuratan input dan output menggunakan Avometer. Hasil pengujian sebagai berikut:

\subsubsection{Switcher Remote AC}

Bentuk rangkaian switcher remote AC dapat dilihat pada Gambar 6. Output rangkaian switcher remote AC dihubungkan ke relay $12 \mathrm{~V}$ di dalam remote AC. Output switcher remote, hasil pengukuran bahwa catu daya yang terukur adalah 11,91V.

$$
\text { Presisi Output } 1=\left(1-\left|\frac{12-11,91}{12}\right|\right) 100=99 \%
$$

Berdasarkan hasil perhitungan presisi di atas bahwa output dari rangkaian switcher remote, tegangan yang keluar sudah mampu mengaktifkan alat yang dicatu dan menyediakan tegangan yang dibutuhkan, yaitu remote AC.

\subsubsection{Switcher Arus Listrik AC}

Bentuk rangkaian switch arus listrik dapat dilihat pada Gambar 7 yang fungsi untuk memutus dan menyambung arus listrik dengan menggunakan IC MOC 3021. Berdasarkan data sheet bahwa IC MOC 3021 mempunyai kemampuan dilalui arus listrik adalah maksimal 220V, $3 \mathrm{~A}$ dan 22 watt. Beban sementara yang digunakan oleh switch arus listrik adalah lampu 9 watt $220 \mathrm{~V}$, menghasilkan lampu dapat menyala dengan terang karena daya yang dikeluarkan oleh rangkaian switch arus listrik lebih tinggi dari daya lampu yang dibutuhkan kurang dari $1 \mathrm{~A}$.

\subsubsection{Rangkaian Output Raspberry Pi}

Bentuk rangkaian input Raspberry Pi dapat dilihat pada Gambar 6. Output rangkaian input Raspberry terhubung dengan rangkaian penguat catu daya dan switch arus listrik. Output yang nantinya dihubungkan dengan switch, hasil pengukuran bahwa catu daya yang terukur adalah $4,82 \mathrm{~V}$, sedangkan ideal input yang bisa diterima oleh rangkaian switch arus listrik berdasarkan IC MOC 3021 adalah 5V. Output yang nantinya dihubungkan dengan penguat catu daya, hasil pengukuran bahwa catu daya yang terukur adalah $3,3 \mathrm{~V}$, sedangkan ideal input yang bisa diterima oleh rangkaian penguat catu daya berdasarkan IC ULN2003 adalah 5V.

$$
\begin{aligned}
& \text { Presisi Output } 1=\left(1-\left|\frac{5-4,82}{5}\right|\right) 100=96 \% \\
& \text { Presisi Output } 2=\left(1-\left|\frac{5-3,33}{5}\right|\right) 100=66 \%
\end{aligned}
$$

Berdasarkan hasil perhitungan presisi di atas bahwa kedua output dari rangkaian input Raspberry $\mathrm{Pi}$ masih cukup besar. Tingkat presisi tersebut masih dapat diabaikan mengingat berada dalam daerah operasi komponen yang dicatu. Tegangan yang keluar sudah mampu mengaktifkan alat yang dicatu dan menyediakan tegangan yang dibutuhkan dua buah alat lainnya, yaitu penguat catu daya dan switch arus listrik.

\subsubsection{Fungsional}

Gambar 14 menunjukkan bahwa remote on ketika sistem Chlorobium pada status on.

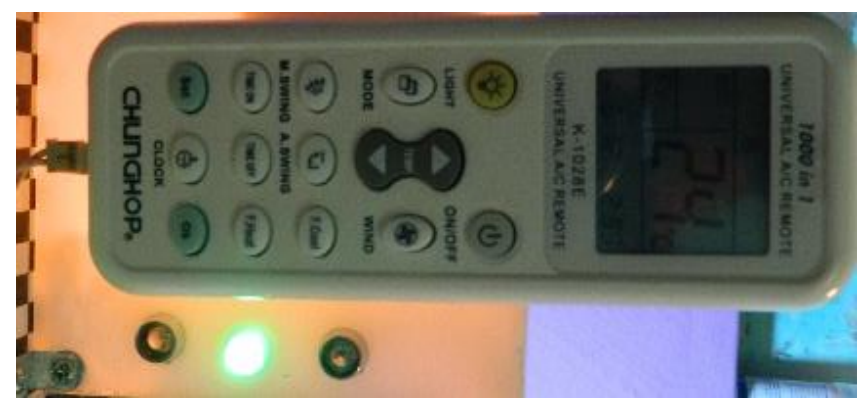

Gambar 14. Remote AC On 
Gambar 15 menunjukkan bahwa remote off ketika sistem Cacao pada status off.

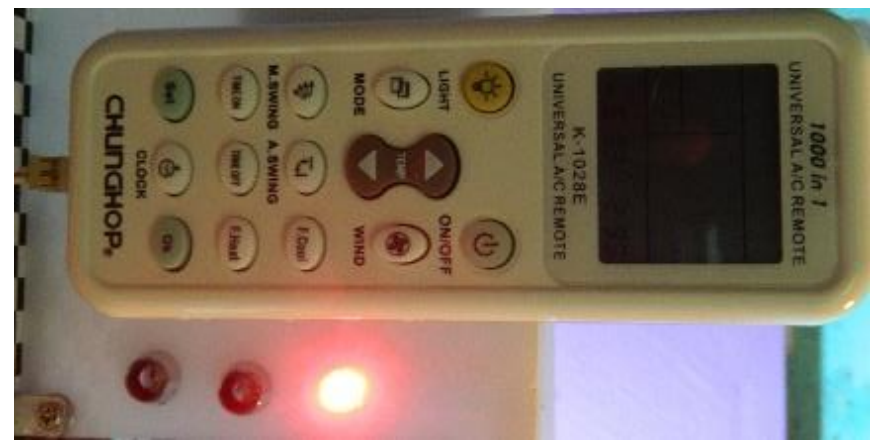

Gambar 15. Remote AC Off

\section{Kesimpulan}

Berdasarkan hasil rancangan dan pembahasan yang telah dibuat, dapat disimpulkan: Sistem kendali on/off jarak jauh untuk perangkat AC (Air Conditioner) dapat dilakukan dengan menekan tombol yang ada pada aplikasi. Pengendalian ini menggunakan Raspberry Pi sebagai alat pengendali jarak jauh yang terhubung menggunakan jaringan komputer seperti LAN dan Wifi. Aplikasi dibuat menggunakan bahasa Visual Basic dan Java.

Rancangan sistem dapat dikembangkan lebih lanjut dengan melakukan penambahan sistem cerdas untuk mendeteksi kondisi ruangan dan status ruangan sehingga AC (Air Conditioner) dapat melakukan on/off secara cerdas.

\section{Referensi}

[1] A. Solikin. "Perancangan Komunikasi Serial Antara Handphone dengan Mikrokontroler." JTET (Jurnal Teknik Elektro dan Komputer) 4.1 (2004).

[2] M. Hamid and Y. Mappeasse. "Kontrol AC Jarak Jauh Dengan Menggunakan Handphone." Media Elektrik. 3.1 (2008).

[3] N. Perkasa. "Sistem Sistem Kontrol Jarak Jauh melalui Jaringan Komputer untuk mengontrol Penerangan Ruangan dan Air Conditioner (AC) Pada Laboratorium STIMIK AMIKOM Yogyakarta." AMIKOM, Yogyakarta. 2013.

[4] M. Subianto. "Rancang Bangun Sistem Lock And Controlling Class Rooms (LCCR) Berbasis Raspberry Pi", in Digital Information \& Systems Conference. Bandung. 2014.

[5] J. Hartono, "Metodologi Penelitian Sistem Informasi." Yogyakarta: Andi. 2008. 
